\title{
Pengaruh Konsentrasi Air Rendaman Sabut Kelapa dan Dosis Pupuk NPK Terhadap Pertumbuhan dan Hasil Tanaman Melon Varietas Action 434
}

\author{
The Influence of Coconut Shell Water Concentration and Dose of NPK Fertilizer for Growth \\ and Yield of Action 434 variety of Water Melon
}

\author{
Romiyadi, endang sufiadi \\ Program Studi Agronomi Fakultas Pertanian Universitas Winaya Mukti \\ anggrek.sahaja@gmail.com \\ Program Studi Agronomi Fakultas Pertanian Universitas Winaya Mukti \\ endangsufiadi@gmail.com
}

\begin{abstract}
The experiment was conducted at Faculty of Agriculture UNWIM Tanjungsari - Sumedang, at the altitude of $850 \mathrm{~m}$ above sea level (asl) with ground Andisol orders from February to April 2008. The purpose of an experiment to study the effect of the interaction between the concentration of coco water immersion at a dose NPK fertilizer on the growth and yield of melon varieties Action 434. The experimental design used was a randomized block design factorial design consisting of two factors and repeated twice. The first factor is the concentration of water immersion coco $(k)$, which consists of five levels, namely: $k 0=$ $0 \%, 25 \%=k 1, k 2=50 \%, k 3=75 \%$, and $k 4=100 \%$. The second factor is the dose of NPK fertilizer $(d)$, which consists of four levels, namely: $d 0=0 \mathrm{~g} \mathrm{plant}^{-1}, d 1=10 \mathrm{~g} \mathrm{plant}^{-1}, d 2=20 \mathrm{~g} \mathrm{plant}^{-1}$, and $d 3=30 \mathrm{~g}$ plant $^{-1}$. The results showed that there is an interaction effect between the concentration of coco water immersion at a dose of NPK fertilizer to the plants age 20 DAT (days after transplanting) and 30 DAT, as well as the number of leaves at the age of 30 DAT. Coco water immersion at a concentration of $25 \%$ gives a better effect on the variable length of the plant, number of leaves, fruit weight per plant, and the quality of the fruit skin. Coco water immersion at a concentration of 50\% gives better effect on the variable sweetness of the fruit flesh. Without dosing NPK fertilizer already gives a better effect on the variable length of the plant, number of leaves, fruit weight per plant, diameter of fruit per plant, and the thickness of the flesh of the fruit. NPK fertilizer dose of $10 \mathrm{~g}$ plant ${ }^{-1}$ give better effect to the variable length of the plant, number of leaves, fruit weight per plant, diameter of fruit per plant, the thickness of the flesh of the fruit, the sweetness of the fruit, and the quality of the fruit skin.
\end{abstract}

Keywords: coco water immersion, NPK, melon.

\section{PENDAHULUAN}

Melon (Cucumis melo L.) merupakan salah satu jenis buah-buahan yang makin populer di dunia, citarasanya manis dan khas serta beraroma sangat harum. Buah melon umumnya dikonsumsi sebagai buah segar untuk pencuci mulut, bahan pencampur minuman segar (es buah), jus, serta bahan baku industri pembuatan minuman (sirup). Selain itu buah melon juga mengandung gizi yang cukup tinggi dengan komposisinya yang lengkap (Rahmat Rukmana, 1994). Menurut Final Prajnanta (1997), buah melon dikenal dalam dunia kesehatan karena banyak mengandung unsur-unsur yang

diperlukan oleh tubuh manusia seperti kalori, lemak, dan karbohidrat yang cukup tinggi. Kandungan vitamin $\mathrm{C}$ pada buah melon juga dapat mencegah terjadinya sariawan dan meningkatkan ketahanan tubuh terhadap penyakit. Saat ini buah melon sering digunakan sebagai terapi kesehatan karena mempunyai khasiat membantu sistem pembuangan, anti kanker (mengandung zat karotenoid), menurunkan resiko stroke dan penyakit jantung, serta mencegah terjadinya penggumpalan darah (mengandung zat adenosin). 
Tabel 1. Kandungan dan Komposisi Gizi Buah Melon Tiap 100 gram Bahan Segar

\begin{tabular}{|c|c|c|}
\hline Komposisi Gizi & Banyaknya (J) & umlah) \\
\hline Kalori (Energi) & 22,00 & Cal \\
\hline Protein & 0,60 & g \\
\hline Lemak & 0,10 & $\mathrm{~g}$ \\
\hline Karbohidrat & 5,30 & $\mathrm{~g}$ \\
\hline Serat & 0,30 & $\mathrm{~g}$ \\
\hline Abu & 0,50 & $\mathrm{~g}$ \\
\hline Kalsium & 12,00 & $\mathrm{mg}$ \\
\hline Fosfor & 30,00 & $\mathrm{mg}$ \\
\hline Kalium & 183,00 & $\mathrm{mg}$ \\
\hline Zat Besi & 0,50 & $\mathrm{mg}$ \\
\hline Natrium & 6,00 & $\mathrm{mg}$ \\
\hline Vitamin A & $2.140,00$ & S.I. \\
\hline Vitamin B1 & 0,03 & $\mathrm{mg}$ \\
\hline Vitamin B2 & 0,02 & $\mathrm{mg}$ \\
\hline Vitamin C & 35,00 & $\mathrm{mg}$ \\
\hline Niacin & 0,80 & $\mathrm{mg}$ \\
\hline Air & 93,50 & $\mathrm{~g}$ \\
\hline Thiamin & 0,045 & $\mathrm{mg}$ \\
\hline Riboflavin & 0,065 & $\mathrm{mg}$ \\
\hline Nicotinamida & 0,5 & $\mathrm{mg}$ \\
\hline
\end{tabular}

Pentingnya kehadiran buah melon bagi manusia, maka diperlukan adanya peningkatan kualitas dan kuantitas produk dengan cara penerapan teknologi tepat guna seperti pemupukkan. Pemupukkan adalah setiap usaha pemberian pupuk yang bertujuan menambah persediaan unsur-unsur hara yang dibutuhkan oleh tanaman untuk peningkatan produksi dan mutu hasil tanaman (Saifuddin Sarief, 1985).

Varietas unggul yang digunakan oleh para petani seperti melon hibrida, memiliki sifat sangat responsif terhadap unsur hara sehingga jika digunakan secara terus menerus, diperkirakan kondisi tanah akan semakin tidak produktif karena banyak kehilangan unsur hara. Kondisi seperti ini dapat diperbaiki dengan penambahan unsur hara secara tepat, yaitu melalui pemupukkan (Novizan, 2005).

Orientasi pertanian modern yang mengejar hasil panen yang sebanyak dan kualitas panen yang prima menjadikan para praktisi pertanian sangat tergantung terhadap penggunaan pupuk tersebut. Tanpa pengetahuan yang memadai, penggunaan pupuk justru menyebabkan penurunan kualitas dan kuantitas produksi. Penggunaan pupuk kimia dalam jangka waktu yang panjang dan tidak terkontrol akan berdampak buruk pada kesuburan, struktur, $\mathrm{pH}$, dan keseimbangan mikroorganisme di dalam tanah (Novizan, 2005).

Menurut Effi Ismawati Musnamar (2003), pertanian organik murni (organic farming) masih belum berjalan normal, terkadang hanya muncul selama beberapa tahun, kemudian menghilang karena masih banyaknya kendala di lapangan. Fungsi pupuk organik di Indonesia masih sebagai pendamping pupuk kimia karena adanya target produksi (ton/ha). Namun pemberian pupuk organik yang dipadukan dengan pupuk kimia dapat meningkatkan produktivitas tanaman dan efisiensi penggunaan pupuk, Dalam jangka waktu yang panjang, kombinasi pupuk organik dan pupuk kimia, dapat mengurangi penggunaan pupuk kimia secara bertahap sehingga dapat tercapai pertanian organik yang seutuhnya. 
Menurut Novizan (2005), pupuk kimia yang umum digunakan para petani adalah pupuk NPK dengan beragam komposisi. Fungsi pupuk majemuk seperti NPK ini diantaranya untuk mempercepat perkembangan benih, sebagai pupuk awal penanaman (starter), dan sebagai pupuk susulan saat tanaman memasuki fase generatif (saat mulai berbunga atau berbuah. Keunggulan lain dari pupuk majemuk ini antara lain kandungan unsur haranya relatif lebih lengkap, efisiensi pemakaian tenaga kerja pada aplikasi pupuk majemuk juga lebih tinggi daripada aplikasi pada pupuk tunggal yang harus diberikan dengan cara dicampur.

Bahan organik yang dapat dijadikan pendamping pupuk kimia adalah air rendaman sabut kelapa. Berdasarkan uji coba Ali Mugni (2006) dalam Subandi Site (2006), penggunaan air rendaman sabut kelapa dapat menggantikan fungsi pupuk $\mathrm{KCl}$, karena dapat menguatkan batang tanaman padi dan meningkatkan hasil panen (Parto dalam BIOcert-Weblog.htm (2004)). Dyah Widiastoety Darmono (2006) dan Livy Winata Gunawan (2006) menyatakan bahwa salah satu media tanam tanaman anggrek yang baik adalah sabut kelapa, karena mengandung unsur $\mathrm{N}, \mathrm{P}, \mathrm{K}, \mathrm{Ca}, \mathrm{Mg}$ yang sangat penting bagi pertumbuhan tanaman.

Berdasarkan data informasi tersebut, perpaduan antara bahan organik air rendaman sabut kelapa dengan pupuk kimia NPK dapat digunakan sebagai metode pemupukan alternatif yang baik terhadap pertumbuhan dan hasil tanaman melon.

\section{Identifikasi Masalah}

Upaya dalam meningkatkan produktivitas tanaman melon dapat dilakukan dengan cara pemupukan. Tetapi pemupukkan yang tidak tepat dapat menimbulkan kerusakan terhadap tanah, sehingga perlu diupayakan alternatif pemupukan yang baik. Perpaduan bahan organik seperti air rendaman sabut kelapa dengan pupuk kimia NPK memberi harapan dalam mengurangi penggunaan pupuk kimia secara bertahap sehingga mampu memberikan pengaruh yang baik terhadap pertumbuhan dan hasil tanaman melon.

Berdasarkan latar belakang yang telah diuraikan di atas, maka dapat diidentifikasi masalah sebagai berikut:

1. Apakah terjadi interaksi antara pemberian air rendaman sabut kelapa dengan pupuk NPK terhadap pertumbuhan dan hasil tanaman melon.

2. Pada konsentrasi air rendaman sabut kelapa dan dosis pupuk NPK berapa yang memberikan pengaruh paling baik terhadap pertumbuhan dan hasil tanaman melon.

\section{Tujuan Penelitian}

Tujuan dari penelitian yang dilakukan adalah untuk mengetahui:

1. Pengaruh interaksi antara konsentrasi air rendaman sabut kelapa dengan dosis pupuk NPK terhadap pertumbuhan dan hasil tanaman melon.

2. Konsentrasi air rendaman sabut kelapa dan dosis pupuk NPK yang memberikan pengaruh paling baik terhadap pertumbuhan dan hasil tanaman melon.

\section{BAHAN DAN METODE}

Percobaan akan dilaksanakan di kebun percobaan Fakultas Pertanian Universitas Winaya Mukti, Kecamatan Tanjungsari, Kabupaten Sumedang. Ketinggian tempat 850 meter di atas permukan laut (dpl) dengan ratarata curah hujan $1.894 \mathrm{~mm} /$ tahun dengan suhu rata-rata harian $25^{\circ} \mathrm{C}$, order tanah yang digunakan adalah andisol. Tipe curah hujan menurut cara perhitungan Schmidt dan Ferguson (1951) dalam Bayong Tjasjono (1999) termasuk tipe C (agak basah). Waktu percobaan dimulai bulan Januari 2008 sampai dengan bulan April 2008. 
Peralatan yang digunakan dalam percobaan kali ini adalah oven, cangkul, golok, gunting, tali rafia, tali kasur, meteran, jangka sorong, ajir bambu kecil, gergaji, plastik sungkup, terpal, kayu kaso/balok, ram kawat, paku, palu, kaleng pembimbitan, lampu 15 watt, lap kain, baki atau ember, gelas ukur, handspayer, timbangan analitik dan standar, pengukur kelembaban, polybag berdiameter 6 $\mathrm{cm}$ dan $60 \mathrm{~cm}$ serta alat tulis.

Bahan yang diperlukan dalam percobaan adalah benih unggul tanaman melon hibrida tipe netted Varietas Action 434, air rendaman sabut kelapa, pupuk NPK (16:16:16), pupuk kandang domba, tanah andisol, pestisida jenis insektisida Decis 2,5 EC dan karbofuran (furadan 3G), jenis fungisida Previcur N, Topsin, Atonik, pupuk daun Gandasil D, Plant Catalyst dan air.

\section{Rancangan Percobaan}

Rancangan lingkungan yang digunakan adalah Rancangan Acak Kelompok Faktorial (RAKF). RAKF ini terdiri dari 2 faktor, yaitu konsentrasi air rendaman sabut kelapa dengan lima taraf dan dosis pupuk NPK dengan empat taraf, serta diulang sebanyak dua kali.

Faktor yang digunakan adalah konsentrasi air rendaman sabut kelapa dengan lima taraf dan dosis pupuk NPK dengan empat taraf.

1. Faktor konsentrasi air rendaman sabut kelapa terdiri dari lima taraf :

- $\mathrm{k}_{0} \quad$ : Konsentrasi air rendaman sabut kelapa $0 \% *$

- $\mathrm{k}_{1} \quad$ : Konsentrasi air rendaman sabut kelapa $25 \% *$

- $\mathrm{k}_{2} \quad$ : Konsentrasi air rendaman sabut kelapa $50 \% *$

- $\mathrm{k}_{3} \quad$ : Konsentrasi air rendaman sabut kelapa $75 \% *$

- $\mathrm{k}_{4} \quad$ : Konsentrasi air rendaman sabut kelapa $100 \% *$
* : perbandingan antara air dengan sabut kelapa 5:1 (dianggap $100 \%$ ).

2. Faktor dosis pupuk NPK (16:16:16) terdiri dari 4 empat taraf :

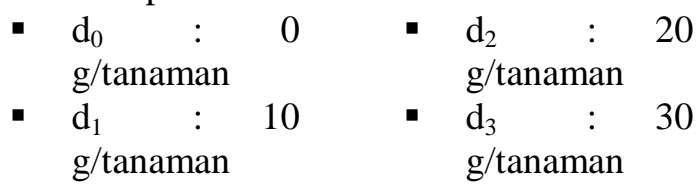

Petak atau plot percobaan seluruhnya berjumlah 40, setiap plot terdiri dari empat tanaman yang ditanam dalam polybag. Penempatan masing-masing perlakuan dilakukan secara acak.

\section{HASIL DAN PEMBAHASAN}

Panjang Tanaman $(\mathrm{cm})$

Berdasarkan Tabel 2 menunjukkan bahwa semakin tinggi konsentrasi air rendaman sabut kelapa maka semakin meningkat pula panjang tanaman melon hingga pada konsentrasi tertentu terjadi titik balik sehingga pertumbuhan panjang tanaman melon menjadi menurun. Sama dengan air rendaman sabut kelapa, pemberian dosis pupuk NPK yang meningkat memberikan pengaruh yang baik terhadap panjang tanaman melon, hingga pada dosis tertentu terjadi titik balik sehingga pertumbuhan panjang tanaman melon menjadi menurun.

Panjang tanaman melon pada umur $20 \mathrm{hspt}$ dan $30 \mathrm{hspt}$ sebagai akibat konsentrasi air rendaman sabut kelapa dan dosis pupuk NPK menunjukkan adanya interaksi. Hasil analisis panjang tanaman melon umur 20 hspt dan 30 hspt disajikan pada Tabel 3. Data tersebut menunjukkan bahwa umumnya pada faktor konsentrasi air rendaman sabut kelapa terhadap dosis pupuk NPK, semakin ditingkatkan konsentasi dan dosisnya maka pertumbuhan panjang tanaman melon semakin meningkat. Namun pada kondisi tertentu, saat konsentrasi dan dosis keduanya terus ditingkatkan terjadi titik balik sehingga pertumbuhan panjang tanaman melon menjadi menurun. Jadi keduanya sama-sama memberikan pengaruh yang mirip. 
Tabel 2. Pengaruh Konsentrasi Air Rendaman Sabut Kelapa dan Dosis Pupuk NPK Terhadap Panjang Tanaman Melon Pada Umur 10 hspt dan 40 hspt

\begin{tabular}{ccccc}
\hline \multirow{2}{*}{ Perlakuan } & \multicolumn{5}{c}{ Rata-rata Panjang Tanaman $(\mathrm{cm})$} \\
\cline { 2 - 5 } & \multicolumn{3}{c}{$10 \mathrm{hspt}$} & $40 \mathrm{hspt}$ \\
\hline Konsentrasi Air Sabut & & & \\
Kelapa : & 7,28 & $\mathrm{a}$ & 166,44 & $\mathrm{a}$ \\
$\mathrm{k}_{0}(0 \%)$ & 7,63 & $\mathrm{a}$ & 171,52 & $\mathrm{a}$ \\
$\mathrm{k}_{1}(25 \%)$ & 7,77 & $\mathrm{a}$ & 165,83 & $\mathrm{a}$ \\
$\mathrm{k}_{2}(50 \%)$ & 7,02 & $\mathrm{a}$ & 159,28 & $\mathrm{a}$ \\
$\mathrm{k}_{3}(75 \%)$ & 7,14 & $\mathrm{a}$ & 161,39 & $\mathrm{a}$ \\
$\mathrm{k}_{4}(100 \%)$ & & & & \\
\hline Dosis NPK : & 6,90 & $\mathrm{a}$ & 174,83 & $\mathrm{~b}$ \\
$\mathrm{~d}_{0}(0 \mathrm{~g} / \tan )$. & 7,55 & $\mathrm{a}$ & 168,07 & $\mathrm{ab}$ \\
$\mathrm{d}_{1}(10 \mathrm{~g} / \tan )$. & 7,74 & $\mathrm{a}$ & 164,34 & $\mathrm{ab}$ \\
$\mathrm{d}_{2}(20 \mathrm{~g} / \tan )$. & $7,28 \mathrm{a}$ & 152,34 & $\mathrm{a}$ \\
$\mathrm{d}_{3}(30 \mathrm{~g} / \tan )$. & & & &
\end{tabular}

Tabel 3. Pengaruh Konsentrasi Air Rendaman Sabut Kelapa dan Dosis Pupuk NPK Terhadap Panjang Tanaman Melon Pada Umur 20 hspt dan 30 hspt

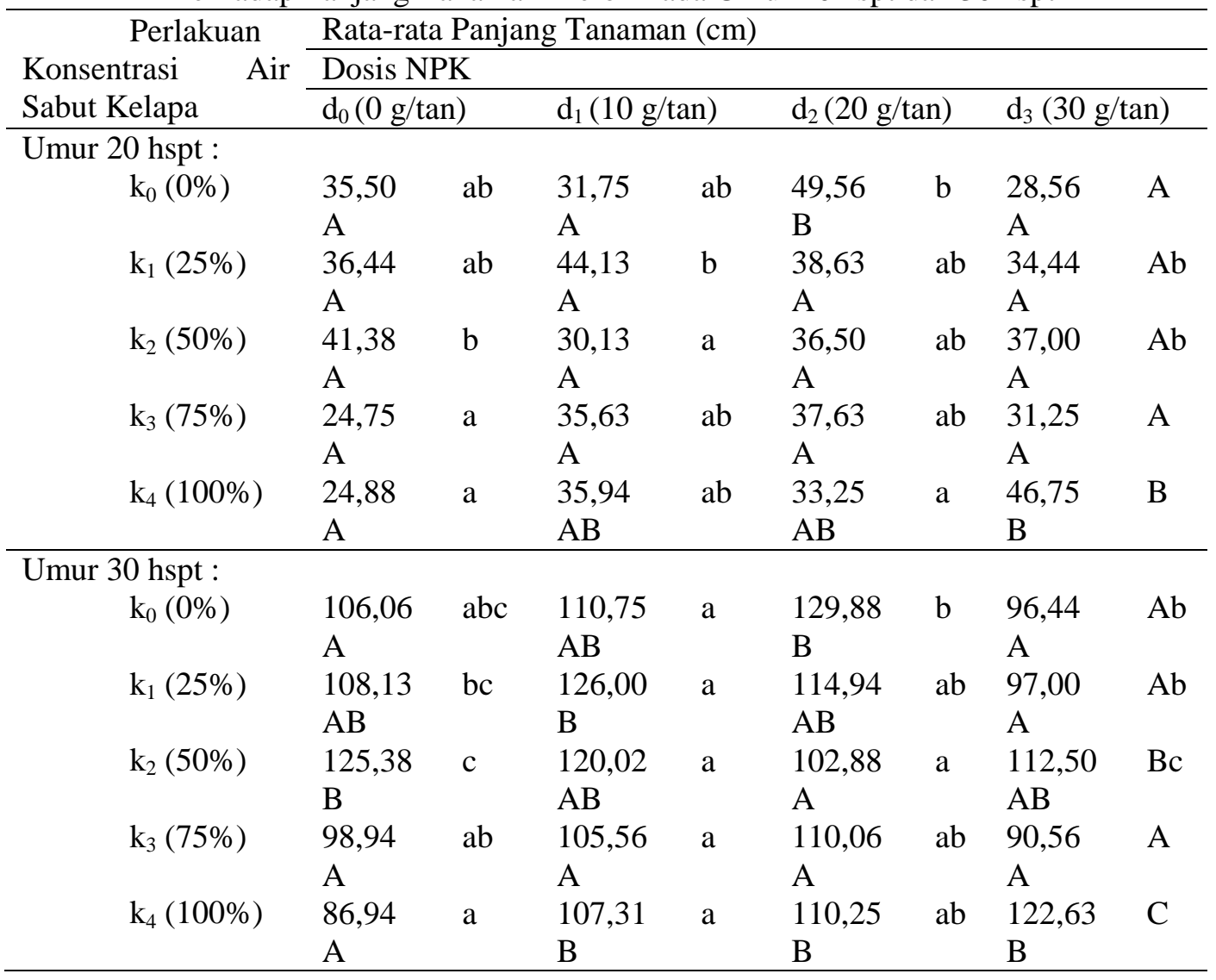


Pada taraf konsentrasi air rendaman sabut kelapa terhadap dosis pupuk NPK umur $20 \mathrm{hspt}$ trend ditunjukkan pada $\mathrm{k}_{2} \mathrm{~d}_{0}, \mathrm{k}_{1} \mathrm{~d}_{1}, \mathrm{k}_{0} \mathrm{~d}_{2}$, dan $\mathrm{k}_{4} \mathrm{~d}_{3}$. Ini menjelaskan bahwa, saat dosis pupuk NPK terus ditingkatkan dari 0 g/tanaman-20 g/tanaman panjang tanaman menjadi meningkat. Tapi saat dosis pupuk NPK terus ditingkatkan menjadi $30 \mathrm{~g} /$ tanaman panjang tanaman menjadi menurun. Sedangkan pada taraf dosis pupuk NPK terhadap konsentrasi air rendaman sabut kelapa trend ditunjukkan pada taraf $\mathrm{k}_{0}$ dan $\mathrm{k}_{4}$. Taraf $\mathrm{k}_{1}$ dan $\mathrm{k}_{2}$ tidak menunjukkan adanya trend.

Pada taraf konsentrasi air rendaman sabut kelapa terhadap dosis pupuk NPK umur $30 \mathrm{hspt}$ trend ditunjukkan pada $\mathrm{k}_{2} \mathrm{~d}_{0}$ dan $\mathrm{k}_{4} \mathrm{~d}_{3}$. Sedangkan $\mathrm{k}_{1}$ dan $\mathrm{k}_{3}$ tidak menunjukkan adanya trend. Pada taraf dosis pupuk NPK terhadap konsentrasi air rendaman sabut kelapa trend ditunjukkan pada taraf $k_{0} d_{2} k_{1} d_{1} k_{2} d_{0}$ dan $k_{4} d_{123}$. Ini berarti dengan adanya peningkatan konsentrasi air rendaman sabut kelapa membuat panjang tanaman meningkat, tapi pada kondisi tertentu panjang tanaman akan kembali menurun saat konsentrasi air rendaman sabut kelapa terus ditingkatkan.

a. Jumlah Daun (helai)

Hasil analisis menunjukkan tidak adanya interaksi pada umur $10 \mathrm{hspt}, 20 \mathrm{hspt}$, dan $40 \mathrm{hspt}$.
Hasil analisis jumlah daun tanaman melon umur $10 \mathrm{hspt}, 20 \mathrm{hspt}$, dan $40 \mathrm{hspt}$ disajikan pada Tabel 4. Tabel 4. menunjukkan bahwa pada umur 10 hspt dan $20 \mathrm{hspt}$ tingkat pertumbuhan jumlah daun tanaman melon sama dengan pengaruhnya pada panjang tanaman. Yaitu mengalami peningkatan jumlah daun saat konsentrasi dan dosis ditingkatkan, namun mengalami penurunan kembali saat konsentrasi dan dosis terus ditingkatkan. Berbeda pada umur 40 hspt, pengaruh yang diberikan oleh peningkatan konsentrasi dan dosis terhadap tanaman menjadikan jumlah daun semakin menurun. Pada taraf dosis pupuk NPK data menunjukan adanya pengaruh yang nyata terhadap jumlah daun pada umur 20 hspt dan 40 hspt, sedangkan pada umur $10 \mathrm{hspt}$ tidak menunjukkan pengaruh yang nyata. Trend pada taraf dosis pupuk NPK ditunjukkan pada taraf $\mathrm{d}_{2}$ pada umur 20 hspt dan $\mathrm{d}_{0}, \mathrm{~d}_{1}, \mathrm{~d}_{2}$ pada umur 40 hspt. Jumlah daun tanaman melon pada umur 30 hspt sebagai akibat konsentrasi air rendaman sabut kelapa dan dosis pupuk NPK menunjukkan adanya interaksi. Hasil analisis jumlah daun tanaman melon umur $30 \mathrm{hspt}$ disajikan pada Tabel 5

Tabel 4. Pengaruh Konsentrasi Air Rendaman Sabut Kelapa dan Dosis Pupuk NPK Terhadap Jumlah Daun Tanaman Melon Pada Umur 10 hspt, 20 hspt, dan 40 hspt

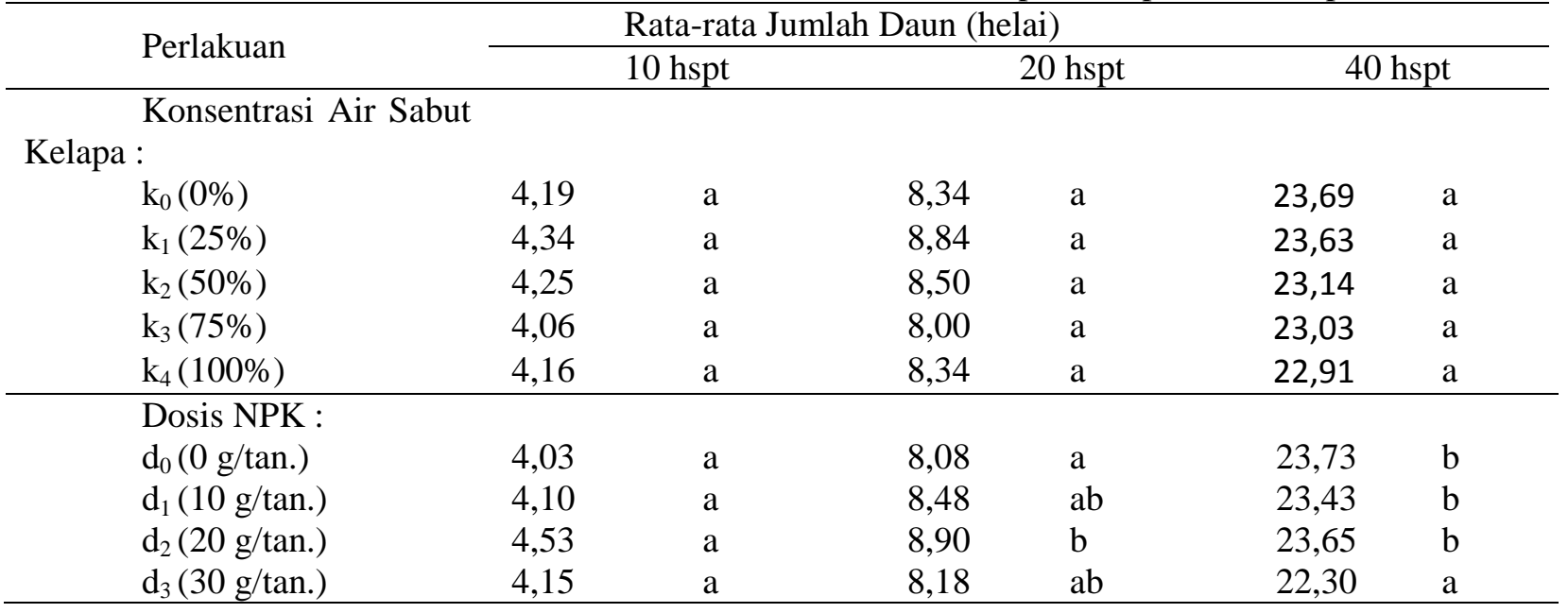


Tabel 5. Pengaruh Konsentrasi Air Rendaman Sabut Kelapa dan Dosis Pupuk NPK Terhadap Jumlah Daun Tanaman Melon Pada Umur 30 hspt

\begin{tabular}{|c|c|c|c|c|c|c|c|c|}
\hline \multirow{3}{*}{\begin{tabular}{l}
\multicolumn{2}{c}{ Perlakuan } \\
Konsentrasi Air \\
Sabut Kelapa
\end{tabular}} & \multicolumn{8}{|c|}{ Rata-rata Jumlah Daun (helai) } \\
\hline & \multicolumn{8}{|c|}{ Dosis NPK } \\
\hline & \multicolumn{2}{|c|}{$\mathrm{d}_{0}(0 \mathrm{~g} / \tan )$} & \multicolumn{2}{|c|}{$\mathrm{d}_{1}(10 \mathrm{~g} / \tan )$} & \multicolumn{2}{|c|}{$\mathrm{d}_{2}(20 \mathrm{~g} / \mathrm{tan})$} & \multicolumn{2}{|c|}{$d_{3}(30 \mathrm{~g} / \tan )$} \\
\hline \multicolumn{9}{|c|}{ Umur $30 \mathrm{hspt}:$} \\
\hline \multirow[t]{2}{*}{$\mathrm{k}_{0}(0 \%)$} & 16,25 & $a b$ & 15,63 & a & 18,38 & a & 15,00 & $\mathrm{a}$ \\
\hline & $\mathrm{AB}$ & & A & & $\mathrm{B}$ & & A & \\
\hline \multirow[t]{2}{*}{$\mathrm{k}_{1}(25 \%)$} & 15,75 & $a b$ & 18,38 & $\mathrm{~b}$ & 17,38 & a & 15,38 & a \\
\hline & A & & B & & $\mathrm{AB}$ & & A & \\
\hline \multirow[t]{2}{*}{$\mathrm{k}_{2}(50 \%)$} & 17,63 & $\mathrm{~b}$ & 15,38 & $\mathrm{a}$ & 16,00 & a & 15,75 & a \\
\hline & A & & A & & A & & A & \\
\hline \multirow[t]{2}{*}{$\mathrm{k}_{3}(75 \%)$} & 14,50 & a & 16,25 & $a b$ & 17,13 & a & 14,75 & a \\
\hline & A & & $\mathrm{AB}$ & & $\mathrm{B}$ & & A & \\
\hline $\mathrm{k}_{4}(100 \%)$ & 14,50 & $\mathrm{a}$ & 16,13 & $\mathrm{ab}$ & 16,63 & a & 17,13 & a \\
\hline
\end{tabular}

Tabel 6. Pengaruh Konsentrasi Air Rendaman Sabut Kelapa dan Dosis Pupuk NPK Terhadap Bobot Buah Per Tanaman

\begin{tabular}{crl}
\hline Perlakuan & \multicolumn{2}{c}{ Rata-rata Bobot Buah Per Tanaman $(\mathrm{g})$} \\
\hline Konsentrasi & Air & \\
Sabut Kelapa : & & $\mathrm{ab}$ \\
$\mathrm{k}_{0}(0 \%)$ & 748,75 & $\mathrm{~b}$ \\
$\mathrm{k}_{1}(25 \%)$ & 831,25 & $\mathrm{ab}$ \\
$\mathrm{k}_{2}(50 \%)$ & 746,88 & $\mathrm{a}$ \\
$\mathrm{k}_{3}(75 \%)$ & 706,88 & $\mathrm{a}$ \\
$\mathrm{k}_{4}(100 \%)$ & 689,90 & $\mathrm{c}$ \\
\hline Dosis NPK : & & $\mathrm{c}$ \\
$\mathrm{d}_{0}(0 \mathrm{~g} / \tan )$. & 836,00 & $\mathrm{~b}$ \\
$\mathrm{~d}_{1}(10 \mathrm{~g} / \tan )$. & 824,75 & $\mathrm{a}$ \\
$\mathrm{d}_{2}(20 \mathrm{~g} / \tan )$. & 716,75 & \\
$\mathrm{~d}_{3}(30 \mathrm{~g} / \tan )$. & 601,42 &
\end{tabular}

Pada Tabel 5. digambarkan pengaruh konsentrasi air rendaman sabut kelapa terhadap dosis pupuk NPK bahwa trend ditunjukkan pada taraf $\mathrm{k}_{2} \mathrm{~d}_{0}$ dan $\mathrm{k}_{1} \mathrm{~d}_{1}$. Sedangkan pengaruh dosis pupuk NPK terhadap konsentrasi air rendaman sabut kelapa trend ditunjukkan pada taraf $\mathrm{k}_{0} \mathrm{~d}_{2}$, $\mathrm{k}_{1} \mathrm{~d}_{1}, \mathrm{k}_{3} \mathrm{~d}_{2}$, dan $\mathrm{k}_{4} \mathrm{~d}_{3}$. Ini berarti dengan adanya peningkatan konsentrasi air rendaman sabut kelapa menjadikan jumlah daun tanaman menjadi meningkat, tetapi akan turun kembali pada kondisi tertentu seiring terus meningkatnya konsentrasi air rendaman sabut kelapa. b. Bobot Buah Per Tanaman (g)

Hasil analisis menunjukkan tidak adanya interaksi antara konsentrasi air rendaman sabut kelapa dengan dosis pupuk NPK. Hasil analisis bobot buah per tanaman disajikan pada Tabel 6 .

Berdasarkan tabel di atas, pengaruh konsentrasi air rendaman sabut kelapa terhadap bobot buah per tanaman terdapat perbedaan yang nyata. Pengaruh paling baik diberikan pada taraf $\mathrm{k}_{1}$, yaitu sebesar $831,25 \mathrm{~g}$. Sedangkan pengaruh paling kecil ditunjukkan pada taraf $\mathrm{k}_{4}$, yaitu sebesar $689,90 \mathrm{~g}$. 
Pengaruh dosis pupuk NPK terhadap bobot buah per tanaman terdapat perbedaan yang nyata. Dosis pupuk NPK yang semakin ditingkatkan, ternyata memberikan pengaruh negatif terhadap bobot buah per tanaman, yaitu bobot buah menjadi semakin menurun. Kedua data tersebut menunjukkan, semakin besar konsentrasi air rendaman sabut kelapa dan dosis pupuk NPK yang diberikan, semakin menurun pula bobot buah yang diperoleh.

\section{c. Diameter Buah Per Tanaman (cm)}

Hasil analisis menunjukkan tidak adanya interaksi antara konsentrasi air rendaman sabut kelapa dengan dosis pupuk NPK. Hasil analisis diameter buah per tanaman disajikan pada Tabel 7. Dosis pupuk NPK memberikan pengaruh yang nyata terhadap diameter buah per tanaman. Pupuk NPK pada dosis $10 \mathrm{~g} /$ tanaman $\left(\mathrm{d}_{1}\right)$ mampu memberikan pengaruh yang paling baik terhadap diameter buah, yaitu sebesar $11,14 \mathrm{~cm}$. Sedangkan bila dosis pupuk NPK terus ditingkatkan menjadi $30 \mathrm{~g} /$ tanaman, diameter buah menjadi menurun.

d. Ketebalan Daging Buah Per Tanaman (cm)

Hasil analisis menunjukkan tidak adanya interaksi antara konsentrasi air rendaman sabut kelapa dengan dosis pupuk NPK. Hasil analisis ketebalan daging buah per tanaman disajikan pada Tabel 8.Tabel 8. menunjukkan bahwa, pengaruh yang diberikan oleh konsentrasi air rendaman sabut kelapa dan dosis pupuk NPK terhadap ketebalan daging buah dengan variabel pengamatan lainnya hampir mirip. Yaitu, mengalami peningkatan saat konsentrasi dan dosis ditingkatkan, namun saat konsentrasi dan dosis terus ditingkatkan ternyata terjadi titik balik dan mengalami penurunan.

Tabel 7. Pengaruh Konsentrasi Air Rendaman Sabut Kelapa dan Dosis Pupuk NPK Terhadap Diameter Buah Per Tanaman

\begin{tabular}{lrr}
\hline Perlakuan & \multicolumn{2}{c}{ Rata-rata Diameter Buah Per Tanaman $(\mathrm{cm})$} \\
\hline Konsentrasi Air Sabut Kelapa : & & \\
$\mathrm{k}_{0}(0 \%)$ & 10,68 & $\mathrm{a}$ \\
$\mathrm{k}_{1}(25 \%)$ & 11,05 & $\mathrm{a}$ \\
$\mathrm{k}_{2}(50 \%)$ & 10,84 & $\mathrm{a}$ \\
$\mathrm{k}_{3}(75 \%)$ & 10,68 & $\mathrm{a}$ \\
$\mathrm{k}_{4}(100 \%)$ & 10,60 & $\mathrm{a}$ \\
\hline Dosis NPK : & & $\mathrm{b}$ \\
$\mathrm{d}_{0}(0 \mathrm{~g} / \mathrm{tan})$. & 11,01 & $\mathrm{~b}$ \\
$\mathrm{~d}_{1}(10 \mathrm{~g} / \mathrm{tan})$. & 11,14 & $\mathrm{~b}$ \\
$\mathrm{~d}_{2}(20 \mathrm{~g} / \tan )$. & 10,79 & $\mathrm{a}$ \\
$\mathrm{d}_{3}(30 \mathrm{~g} / \tan )$. & 10,15 & \\
& &
\end{tabular}

Tabel 8. Pengaruh Konsentrasi Air Rendaman Sabut Kelapa dan Dosis Pupuk NPK Terhadap Ketebalan Daging Buah Per Tanaman

\begin{tabular}{lcc}
\hline Perlakuan & Rata-rata Ketebalan Daging Buah Per Tanaman $(\mathrm{cm})$ \\
\hline Konsentrasi Air Sabut Kelapa : & & \\
$\mathrm{k}_{0}(0 \%)$ & 2,35 & $\mathrm{a}$ \\
$\mathrm{k}_{1}(25 \%)$ & 2,41 & $\mathrm{a}$ \\
$\mathrm{k}_{2}(50 \%)$ & 2,29 & $\mathrm{a}$ \\
$\mathrm{k}_{3}(75 \%)$ & 2,23 & $\mathrm{a}$ \\
$\mathrm{k}_{4}(100 \%)$ & 2,23 & $\mathrm{a}$ \\
\hline Dosis NPK : & & \\
$\mathrm{d}_{0}(0 \mathrm{~g} / \tan )$. & 2,35 & $\mathrm{~b}$ \\
$\mathrm{~d}_{1}(10 \mathrm{~g} / \tan )$. & 2,46 & $\mathrm{~b}$ \\
$\mathrm{~d}_{2}(20 \mathrm{~g} / \tan )$. & 2,29 & $\mathrm{ab}$ \\
$\mathrm{d}_{3}(30 \mathrm{~g} / \tan )$. & 2,13 & $\mathrm{a}$ \\
\hline
\end{tabular}


Dosis pupuk NPK pada taraf $10 \mathrm{~g} /$ tanaman $\left(\mathrm{d}_{1}\right)$ memberikan pengaruh paling baik terhadap ketebalan daging buah, yaitu sebesar $2,46 \mathrm{~cm}$. Sedangkan bila dosis pupuk NPK terus ditingkatkan menjadi $30 \mathrm{~g} /$ tanaman, ketebalan daging buah menjadi menurun.

e. Kadar Gula Daging Buah Melon (\% brix)

Hasil analisis menunjukkan tidak adanya interaksi antara konsentrasi air rendaman sabut kelapa dengan dosis pupuk NPK. Hasil analisis kadar gula daging buah per tanaman disajikan pada Tabel 9. Berdasarkan data Tabel 9. di atas, kedua perlakuan tidak menunjukkan pengaruh yang nyata. Namun demikian, perlakuan konsentrasi air rendaman sabut kelapa dan dosis pupuk NPK ternyata memberikan pengaruh yang cukup baik terhadap kadar gula daging buah, meskipun tidak nyata. Bila diandingkan dengan buah melon yang beredar di pasaran, buah melon hasil percobaan ini memiliki kadar gula yang lebih unggul. Hal ini dibuktikan dengan melakukan perbandingan dengan buah melon yang ada di pasaran, yang hanya memiliki kadar gula sebesar $7,7 \%$ brix.

f. Uji Organoleptik Terhadap Aroma Buah

Hasil analisis menunjukkan tidak adanya interaksi antara konsentrasi air rendaman sabut kelapa dengan dosis pupuk NPK. Hasil analisis kualitas aroma buah melon disajikan pada Tabel 10. Berdasarkan Tabel 10. konsentrasi air rendaman sabut kelapa dan dosis pupuk NPK memberikan pengaruh yang tidak nyata terhadap kualitas aroma buah. Panelis menyatakan "agak harum" pada semua taraf $\mathrm{k}$ dan taraf $\mathrm{d}$. Ini menunjukkan bahwa semakin besar konsentrasi air rendaman sabut kelapa dan dosis pupuk NPK yang diberikan, tidak mempengaruhi kualitas keharuman daging buah.

Tabel 9. Pengaruh Konsentrasi Air Rendaman Sabut Kelapa dan Dosis Pupuk NPK Terhadap Kadar Gula Daging Buah

\begin{tabular}{lll}
\hline Perlakuan & \multicolumn{2}{c}{ Rata-rata Kadar Gula Daging Buah (\% brix) } \\
\hline Konsentrasi Air Sabut Kelapa : & 10,08 & $\mathrm{a}$ \\
$\mathrm{k}_{0}(0 \%)$ & 9,73 & $\mathrm{a}$ \\
$\mathrm{k}_{1}(25 \%)$ & 10,34 & $\mathrm{a}$ \\
$\mathrm{k}_{2}(50 \%)$ & 9,69 & $\mathrm{a}$ \\
$\mathrm{k}_{3}(75 \%)$ & 9,43 & $\mathrm{a}$ \\
$\mathrm{k}_{4}(100 \%)$ & & \\
Dosis NPK : & 9,46 & $\mathrm{a}$ \\
$\mathrm{d}_{0}(0 \mathrm{~g} / \tan )$. & 10,09 & $\mathrm{a}$ \\
$\mathrm{d}_{1}(10 \mathrm{~g} / \tan )$. & 10,05 & $\mathrm{a}$ \\
$\mathrm{d}_{2}(20 \mathrm{~g} / \tan )$. & 9,82 & $\mathrm{a}$ \\
$\mathrm{d}_{3}(30 \mathrm{~g} / \tan )$. & & \\
\hline
\end{tabular}

Tabel 10. Pengaruh Konsentrasi Air Rendaman Sabut Kelapa dan Dosis Pupuk NPK Terhadap Kualitas Aroma Buah Melon

\begin{tabular}{lcc}
\hline Perlakuan & \multicolumn{2}{c}{ Kualitas Aroma Daging Buah } \\
\hline Konsentrasi Air Sabut Kelapa : & 3,15 & $\mathrm{a}$ \\
$\mathrm{k}_{0}(0 \%)$ & 3,29 & $\mathrm{a}$ \\
$\mathrm{k}_{1}(25 \%)$ & 3,00 & $\mathrm{a}$ \\
$\mathrm{k}_{2}(50 \%)$ & 3,10 & $\mathrm{a}$ \\
$\mathrm{k}_{3}(75 \%)$ & 3,35 & $\mathrm{a}$ \\
$\mathrm{k}_{4}(100 \%)$ & & $\mathrm{a}$ \\
\hline Dosis NPK : & 3,08 & $\mathrm{a}$ \\
$\mathrm{d}_{0}(0 \mathrm{~g} / \mathrm{tan})$. & 3,13 & $\mathrm{a}$ \\
$\mathrm{d}_{1}(10 \mathrm{~g} / \mathrm{tan})$. & 3,20 & $\mathrm{a}$ \\
$\mathrm{d}_{2}(20 \mathrm{~g} / \tan )$. & 3,32 & \\
$\mathrm{~d}_{3}(30 \mathrm{~g} / \tan )$. & & \\
\hline
\end{tabular}


g. Uji Organoleptik Terhadap Kemanisan Daging Buah

Hasil analisis menunjukkan tidak adanya interaksi antara konsentrasi air rendaman sabut kelapa dengan dosis pupuk NPK. Hasil analisis kualitas kemanisan daging buah melon disajikan pada Tabel 11.. Berdasarkan Tabel 11. konsentrasi air rendaman sabut kelapa dengan dosis pupuk NPK memberikan pengaruh yang nyata terhadap rasa manis buah berdasarkan uji organoleptik. Panelis menyatakan "manis" pada taraf $\mathrm{k}_{0}, \mathrm{k}_{2}$, dan $\mathrm{k}_{3}$. Sedangkan $\mathrm{k}_{1}$ dan $\mathrm{k}_{4}$, panelis menyatakan "agak manis". Pada taraf dosis pupuk NPK, panelis menyatakan "manis" pada taraf $d_{0}, d_{1}$, dan $d_{2}$. Sedangkan $d_{3}$, panelis menyatakan "agak manis". Ini menunjukkan bahwa semakin besar konsentrasi air rendaman sabut kelapa dan dosis pupuk NPK yang diberikan, kualitas kulit buah semakin menurun. h. Uji Organoleptik Terhadap Kulit Buah

Hasil analisis menunjukkan tidak adanya interaksi antara air rendaman sabut kelapa dengan dosis pupuk NPK. Hasil analisis kualitas kulit buah melon disajikan pada Tabel 12 . Berdasarkan Tabel 12. konsentrasi air rendaman sabut kelapa dengan dosis pupuk NPK memberikan pengaruh yang nyata terhadap kualitas kulit buah berdasarkan uji organoleptik. Panelis menyatakan "menarik" pada taraf $\mathrm{k}_{0}, \mathrm{k}_{1}$, $\mathrm{k}_{2}$, dan $\mathrm{k}_{3}$. Sedangkan $\mathrm{k}_{4}$, panelis menyatakan "agak menarik". Pada taraf dosis pupuk NPK, panelis menyatakan "menarik" pada taraf $\mathrm{d}_{0}, \mathrm{~d}_{1}$, dan $d_{2}$. Sedangkan $d_{3}$, panelis menyatakan "agak menarik". Ini menunjukkan bahwa semakin besar konsentrasi air rendaman sabut kelapa dan dosis pupuk NPK yang diberikan, kualitas kulit buah semakin menurun.

Tabel 11. Pengaruh Konsentrasi Air Rendaman Sabut Kelapa dan Dosis Pupuk NPK Terhadap Kualitas kemanisan Daging Buah Melon

\begin{tabular}{lll}
\hline Perlakuan & \multicolumn{2}{c}{ Kualitas Kemanisan Daging Buah } \\
\hline Konsentrasi Air Sabut Kelapa : & 2,77 & $\mathrm{ab}$ \\
$\mathrm{k}_{0}(0 \%)$ & 3,06 & $\mathrm{~b}$ \\
$\mathrm{k}_{1}(25 \%)$ & 2,68 & $\mathrm{a}$ \\
$\mathrm{k}_{2}(50 \%)$ & 2,91 & $\mathrm{ab}$ \\
$\mathrm{k}_{3}(75 \%)$ & 3,03 & $\mathrm{~b}$ \\
$\mathrm{k}_{4}(100 \%)$ & & \\
Dosis NPK : & 2,84 & $\mathrm{ab}$ \\
$\mathrm{d}_{0}(0 \mathrm{~g} / \mathrm{tan})$. & 2,70 & $\mathrm{a}$ \\
$\mathrm{d}_{1}(10 \mathrm{~g} / \tan )$. & 2,93 & $\mathrm{ab}$ \\
$\mathrm{d}_{2}(20 \mathrm{~g} / \tan )$. & 3,08 & $\mathrm{~b}$ \\
$\mathrm{~d}_{3}(30 \mathrm{~g} / \tan )$. & & \\
\hline
\end{tabular}

Tabel 12. Pengaruh Konsentrasi Air Rendaman Sabut Kelapa dan Dosis Pupuk NPK Terhadap Hasil Kualitas Kulit Buah Melon

\begin{tabular}{lrc}
\hline Perlakuan & & Kualitas Penampilan Kulit Daging Buah \\
\hline Konsentrasi Air Sabut Kelapa : & & \\
$\mathrm{k}_{0}(0 \%)$ & 2,86 & $\mathrm{~b}$ \\
$\mathrm{k}_{1}(25 \%)$ & 2,76 & $\mathrm{a}$ \\
$\mathrm{k}_{2}(50 \%)$ & 2,65 & $\mathrm{a}$ \\
$\mathrm{k}_{3}(75 \%)$ & 2,86 & $\mathrm{ab}$ \\
$\mathrm{k}_{4}(100 \%)$ & 3,21 & $\mathrm{~b}$ \\
\hline Dosis NPK : & & \\
$\mathrm{d}_{0}(0 \mathrm{~g} / \tan )$. & 2,78 & $\mathrm{~b}$ \\
$\mathrm{~d}_{1}(10 \mathrm{~g} / \tan )$. & 2,53 & $\mathrm{a}$ \\
$\mathrm{d}_{2}(20 \mathrm{~g} / \tan )$. & 2,88 & $\mathrm{ab}$ \\
$\mathrm{d}_{3}(30 \mathrm{~g} / \tan )$. & 3,29 & $\mathrm{c}$ \\
\hline
\end{tabular}


Tabel 13. Pengaruh Konsentrasi Air Rendaman Sabut Kelapa dan Dosis Pupuk NPK Terhadap Kesukaan Buah Melon

\begin{tabular}{crc}
\hline Perlakuan & \multicolumn{2}{c}{ Kualitas Kesukaan Buah } \\
\hline Konsentrasi & Air & \\
Sabut Kelapa : & & $\mathrm{b}$ \\
$\mathrm{k}_{0}(0 \%)$ & 2,78 & $\mathrm{~b}$ \\
$\mathrm{k}_{1}(25 \%)$ & 3,11 & $\mathrm{a}$ \\
$\mathrm{k}_{2}(50 \%)$ & 2,80 & $\mathrm{~b}$ \\
$\mathrm{k}_{3}(75 \%)$ & 2,96 & $\mathrm{~b}$ \\
$\mathrm{k}_{4}(100 \%)$ & 3,11 & \\
\hline Dosis NPK : & & $\mathrm{a}$ \\
$\mathrm{d}_{0}(0 \mathrm{~g} / \tan )$. & 2,93 & $\mathrm{a}$ \\
$\mathrm{d}_{1}(10 \mathrm{~g} / \tan )$. & 2,78 & $\mathrm{a}$ \\
$\mathrm{d}_{2}(20 \mathrm{~g} / \tan )$. & 2,94 & $\mathrm{~b}$ \\
$\mathrm{~d}_{3}(30 \mathrm{~g} / \tan )$. & 3,17 &
\end{tabular}

i. Uji Organoleptik Terhadap Kesukaan Buah

Data pengaruh konsentrasi air rendaman sabut kelapa dan dosis pupuk NPK terhadap kesukaan buah melon terdapat pada Lampiran 24.. Hasil analisis menunjukkan tidak adanya interaksi antara air rendaman sabut kelapa dengan dosis pupuk NPK. Hasil analisis kesukaan buah melon disajikan pada Tabel 13. Data tersebut menjelaskan bahwa konsentrasi air rendaman sabut kelapa dan dosis pupuk NPK memberikan pengaruh yang nyata terhadap kesukaan keseluruhan kriteria buah berdasarkan uji organoleptik. Panelis menyatakan rasa "suka" pada taraf $\mathrm{k}_{0}, \mathrm{k}_{2}$ dan $\mathrm{k}_{3}$, sedangkan $\mathrm{k}_{1}$ dan $\mathrm{k}_{4}$ panelis menyatakan "agak suka". Pada taraf dosis pupuk NPK, panelis menyakatakan rasa "suka" pada taraf $\mathrm{d}_{0}, \mathrm{~d}_{1}$, dan $\mathrm{d}_{2}$, sedangkan taraf $\mathrm{d}_{3}$, panelis menyatakan "agak suka". Ini menunjukkan bahwa semakin besar konsentrasi air rendaman sabut kelapa dan dosis pupuk NPK yang diberikan, kesukaan panelis terhadap buah semakin menurun.

\section{KESIMPULAN}

Hasil percobaan pengaruh konsentrasi air rendaman sabut kelapa dan dosis pupuk NPK terhadap pertumbuhan dan hasil tanaman melon varietas Action 434, dapat disimpulkan sebagai berikut :

1. Terdapat pengaruh interaksi antara konsentrasi air rendaman sabut kelapa dengan dosis pupuk NPK terhadap panjang tanaman umur 20 hspt dan $30 \mathrm{hspt}$, serta terhadap jumlah daun pada umur $30 \mathrm{hspt}$.

2. Air rendaman sabut kelapa pada konsentrasi $25 \%$ dan dosis pupuk NPK $10 \mathrm{~g} /$ tanaman memberikan pengaruh yang lebih baik terhadap semua variabel pengamatan.

3. Air rendaman sabut kelapa yang melebihi $25 \%$ dan dosis pupuk NPK yang melebihi 10 g/tanaman, menurunkan kualitas dan kuantitas tanaman melon varietas Action 434.

\section{Saran}

Secara mandiri untuk meningkatkan pertumbuhan dan hasil tanaman melon varietas Action 434 disarankan menggunakan air rendaman sabut kelapa dengan konsentrasi $25 \%$. Sedangkan dosis pupuk NPK sebanyak $10 \mathrm{~g}$ per tanaman. Perlu dilakukan penelitian lebih lanjut untuk mendapatkan informasi yang lebih lengkap mengenai pengaruh konsentrasi air rendaman sabut kelapa dan dosis pupuk NPK pada tempat dan varietas tanaman melon yang berbeda. Perlu juga memperhatikan pengaplikasian unsur hara mikro dipenelitian berikutnya, untuk mendapatkan hasil percobaan yang lebih optimal.

\section{DAFTAR PUSTAKA}

Afandie Rosmarkam dan Nasih Widya Yuwono. 2002. Ilmu Kesuburan Tanah. Kanisius, Yogyakarta. 
Agung Pratowo. 2004. Bertani Secara Alami Menguntungkan dan Menyehatkan (Kutipan dari Koran Tempo, edisi 09 Maret 2004), BIOcert-Weblog.htm.

Bayong Tjasjono. 1999. Klimatologi Umum. Penerbit ITB Bandung, Bandung.

Budi Samadi. 1995. Usahatani Melon. Kanisius, Yogyakarta.

Doedyanto $d k k$. 1978. Bercocok Tanam (Jilid II : Untuk Sekolah Pertanian Pembangunan). CV. Jasaguna, Jakarta.

Dyah Widiastoety Darmono. 2004. Bertanam Anggrek (Panduan Praktis Untuk Hobiis Tentang Cara Menanam, Merawat, dan Membungakan Anggrek). Penebar Swadaya, Jakarta.

Effi Ismawati Musnamar. 2003. Pupuk Organik (Cair dan Padat, Pembuatan dan Aplikasi). Penebar Swadaya, Jakarta.

Effi Ismawati Musnamar. 2003. Pupuk Organik Padat (Pembuatan dan Aplikasi). Penebar Swadaya, Jakarta.

Final Prajnanta. 1997. Melon : Pemeliharaan Secara Intensif dan Kiat Sukses Beragribisnis. Penebar Swadaya, Jakarta.

Gembong Tjitrosoepomo. 1988. Taksonomi Tumbuhan (Spermatophyta). Gadjah Mada University Press, Yogyakarta.

Kemas Ali Hanafiah. 1991. Rancangan Percobaan (Teori dan Aplikasi). Rajawali Pers (PT Raja Grafindo Persada), Jakarta.

Livy Winata Gunawan. 2006. Budidaya Anggrek (Menjawab Semua
Permasalahan Budidaya yang Anda

Hadapi). Penebar Swadaya, Jakarta.

Novizan. 2005. Petunjuk Pemupukkan yang Efektif (Kiat Mengatasi Permasalahan Praktis - edisi revisi). Agromedia Pustaka, Jakarta.

Nur Tjahjadi. 1989. Bertanam Melon. Kanisius, Yogyakarta.

Pracaya. 2007. Hama dan Penyakit Tanaman (edisi revisi), Jakarta.

Rachman Sutanto. 2002. Pertanian Organik (Menuju Pertanian Alternatif dan Berkelanjutan). Kanisius, Yogyakarta.

Rahmat Rukmana. 1995. Melon Hibrida. Kanisius, Yogyakarta.

Saifuddin Sarief. 1985. Kesuburan dan Pemupukkan Tanah Pertanian. Pustaka Buana, Bandung.

Salisbury dan Rose. 1995. Fisiologi

Tumbuhan (Jilid 1). Penerbit ITB Bandung, Bandung.

Setiadi dan Parimin. 2006. Bertanam

Melon (edisi revisi). Penebar Swadaya,

Jakarta.

Subandi. 2006. Pupuk Cair Dari Sabut Kelapa. http://subandi.blogsome.com, 24 November 2006.

Tim Penyusun Kamus PS. 1997. Kamus Pertanian Umum. Penebar Swadaya, Jakarta.

2005. Phalaenopsis (Trubus Info Kit). PT Trubus Swadaya, Jakarta. 